\title{
EFEK PAPARAN KADMIUM (CD) TERHADAP FUNGSI GINJAL PEKERJA BENGKEL LAS
}

\author{
EFFECT CADMIUM EXPOSURE ON RENAL FUNCTION \\ OF WELDING WORKERS
}

\author{
Hernayanti, Slamet Santoso, Sri Lestari, Lucky Prayoga, Kamsinah, \\ Rochmatino \\ Fakultas Biologi Universitas Jenderal Soedirman
}

\begin{abstract}
Cadmium is one of the heavy metals that has nephroxic effect and dangerous to human health, especiallywelding workers. If cadmium enters the body will bind to metallotionein protein. This process can increase the formation of free radical compounds, thereby induced lipid peroxidation which damage kidney organ and may cause impaired the renal function. Decreased renal function is characterized by an increase of $\beta 2$-Microglobulin and creatinine level. The aim of this study are to know effect of $\mathrm{Cd}$ exposure to renal function indicated by increasing of $\mathrm{Cd}$, creatinine and $\beta 2-\mathrm{M}$ level. Research design used case control. Research subjects consist of thirty welding workers in Purwokerto with a period of working more than 3 years as case subjects and control subjects come from Pamijen village Baturaden. Data of $\mathrm{Cd}$, creatinine and $\beta 2-\mathrm{M}$ level were analyzed by $\mathrm{t}$ independent. Result of this research showed that in case subjects occur an increase of Cd, creatinine and $\beta 2-\mathrm{M}$ level and have higher level compare with control subjects.It can be concluded that Cd exposure has an effect on renal disfunction which indicated by increasing blood Cd level, creatinine and $\beta 2-\mathrm{M}$ level.
\end{abstract}

Key words : Cadmium, metallothionein, renal disfunction

\begin{abstract}
ABSTRAK
Kadmium merupakan salah satu logam berat yang bersifat nefroksik dan membahayaka kesehatan manusia, terutama pekerja bengkel las.. Kadmium masuk ke dalam tubuh berikatan dengan metalotionin membentuk ikatan $\mathrm{Cd}+\mathrm{Mt}$ akan terdeposit di organ ginjal dan menginduksit erbentuknya radikal bebas sehingga mengakibatkan peroksidasi lipid yang dapat merusak organ ginjal, ditandai dengan peningkatan kreatinin dan $\beta 2$ mikroglobulin. Tujuan penelitian adalah untuk mengetahui efek paparan $\mathrm{Cd}$ terhadap fungsi ginjal pekerjabengkel las ditinjau dari parameter kreatinin dan $\beta 2$ mikroglobulin $(\beta 2-\mathrm{M})$. Rancangan penelitian menggunakan rancangan kasus kontrol. Subyek penelitian terdiri dari 30 orang pekerja bengkel las di Purwokerto dengan masa kerja lebih dari 3 tahun sebagai subyek kasus dan subyek kontrol dari desaPamijenBaturaden yang mewakili bukan pekerja bengkel las. Data dianalisis menggunakan uji t independent. Hasil penelitian menunjukkan kadar Cd darah, kreatinin darah dan $\beta 2$ mikroglobulin pada subyek kasus berbeda nyatadibandingkan dengan subyek kontrol. Kadar $\mathrm{Cd}$, kreatinin darah dan $\beta 2$ mikroglobulin subyek kasus lebih tinggid ibandingkan subyek kontrol. Kesimpulan penelitian paparan Cd berpengaruh terhadap penurunan fungsi ginjal pekerjabengkel las yang ditandai dengan peningkatan kadar Cd darah, kreatinin dan $\beta 2-\mathrm{M}$.
\end{abstract}

Key words :kadmium, metalotionin, disfungsi ginjal.

\section{PENDAHULUAN}

Logam berat kadmium (Cd) merupakan salah satu zat pencemar berbahaya bagi lingkungan. Bertambahnya pencemaran logam berat sebanding dengan
meningkatnya aktivitas yang dilakukan oleh manusia khususnya di bidang industri. Logam kadmium digunakan di berbagai bidang seperti 
pelapisan logam, peleburan dan pemurnian Zinc (Zn), pengelasan, pewarna, baterai, minyak pelumas, bahan bakar, pupuk dan pestisida (Palar, 2008., Chunhabundit, 2016). Limbah cair hasil industri dapat mengalir mencemari sungai maupun laut sedangkan kadmium pada pupuk dan pestisida dapat mencemari bahan pangan hasil produksi pertanian.

Kadmium dapat masuk melalui jalur inhalasi dari polutan udara yang dihasilkan oleh aktivitas industri seperti proses pengelasan dan pemurnian logam. Kadmium juga dapat masuk melalui jalur oral yaitu melalui makanan yang tercemar Cd.Kadmium merupakan senyawa yang persisten di lingkungan dengan waktu paruh 3040 tahun ( Palar,2008; Satarug and Garret.,2010), sehingga paparan Cd baik akut maupun kronis sangat berbahaya bagi kesehatan manusia terutama terhadap organ ginjal, yang merupakan sasaran utama dari Cd. Kadmium yang masuk tubuh akan berikatan dengan protein metalotionin. Ikatan Cd dan metalotionin bersifat stabildan dapat memicu peningkatan radikal bebas dalam hati dan ginjal, sehingga dapat menimbulkan kerusakan pada kedua organ tersebut ( Faroon et al., 2012; Sabath et al., 2012).

Pekerja bengkel las merupakan kelompok yang beresiko terkena paparan Cd.Penelitian Santoso dan Hernayanti,(2016) menemukan kejadian hipertensi pada pekerja bengkel las di Purwokerto dari 40 probandus yang diperiksa kadar Cd darahnya ditemukan 72,5\% mengalami hipertensi.Wohingati et al., 2014 menemukan adanya Cd dalam urin petani tanaman hias di Baturaden melebihi normal $(>2 \mu \mathrm{g} / \mathrm{L})$ dan disertai dengan penurunan Laju Filtrasi Glomerulus (LFG), hal ini menunjukkan adanya gangguan pada ginjal akibat paparan kadmium.

Permasalahan yang timbul adalah masih jarang dilakukan penelitian tentang dampak pencemaran Cd terhadap kesehatan pekerja yang sehari-hari kontak dengan Cd seperti pekerja bengkel las, padahal Cd merupakan zat nefrotoksik yang dapat merusak ginjal.Untuk mengetahui efek paparan Cd terhadap fungsi ginjal pekerja bengkel las maka dilakukan penelitian ini. Tujuan penelitian 
adalah untuk mengetahui efek paparan Cd terhadap kadar Cd darah pekerja bengkel las dan fungsi ginjal pekerja melalui pemeriksaan $\beta 2$ mikroglobulin dan kreatinin darah. Dengan melakukan penelitian ini diharapkan dapat melakukan pencegahan lebih dini terhadap paparan Cd pada pekerja bengkel las.

\section{METODE}

Penelitian dilakukan mulai bulan Juli sampai dengan September 2018. Pengambilan darah pekerja bengkel las dilakukan di bengkel di sekitar Purwokerto. Pemeriksaan kreatinin dan $\beta 2-\mathrm{M}$ dilakukan di Laboratorium Utama Medico Labora Purwokerto.

Bahan yang digunakan berupakit komersial ELISA Human B2- Mikroglobulin, serta reagen kreatinin Dyasis. Alat yang digunakan antara lain vaccumed EDTA, AAS, Elisa Reader dan Spektrofotometer merk Riele.

Rancangan penelitian menggunakan rancangan case control. Subyek kasus pada penelitian ini adalah pekerja bengkel las di Purwokerto. Pengambilan sampel dilakukan di Laboratorium
Utama Medico Labora, dengan kriteria inklusi : responden dengan masa kerja minimal 3 tahun yang bersedia menandatangani Informed Consent dan kriteria eksklusi adalah responden yang tidak hadir pada saat penelitian dilakukan. Sebagai subyek kontrol adalah bukan pekerja bengkel las diambil dari daerah Pamijen Baturaden. Pengambilan sampel dilakukan di Balai Desa Pamijen. Peubah bebas: berupa kadar Cd darah pada pekerja bengkel las, sedangkan peubah tergantung berupa perubahan kadar kreatinin dan $\beta 2-\mathrm{M}$ dalam darah pekerja bengkel las. Parameter yang diamati: kadar Cd, kreatinin dan $\beta 2-\mathrm{M}$ dalam darah pekerja bengkel las.

$$
\text { Sebelum dilakukan }
$$

penelitian, peneliti mengajukan Etichal Clearance ke Komisi Etik Fakultas Kedokteran Unsoed dan mendapatkan persetujuan dengan NoRef:1151/KEPK/III/2018.

Pemeriksaan Cd darah dengan alat AAS (ACGIH, 2000) pada panjang gelombang228,6 nm dan kuat arus $3,5 \mathrm{~mA}^{0}$ menggunakan larutan standar $\mathrm{CdSO}_{4}$ konsentrasi 2 ppm, 5 ppm, 9 ppm dan 15 ppm. Pemeriksaan kreatinin darah 
menggunakan metode Jaffe kinetik dan alat spektrofotometer Riele. Untuk pemeriksaan $\beta 2-\mathrm{M}$ dengan metode ELISA Sandwich dan pembacaan menggunakan alat ELISA Reader merk Labotron. Data hasil pengukuran parameter, kreatinin, $\quad \mathrm{Cd}$ darah dan $\beta-2$ mikroglobulin subyek kasus dan

Tabel 1. Kadar Cd darah subyek kasus dan subyek kontrol

\begin{tabular}{ll}
\hline Kelompok & Kadar Cd darah (ppm) \\
Subyek kontrol & $0,12 \pm 0,034^{\mathrm{a}}$ \\
Subyek kasus & $1,092 \pm 0,5^{\mathrm{b}}$
\end{tabular}

Keterangan $: p=0, n=30$. Angka yang diikuti huruf yangtidak sama pada setiap kolom menunjukkan perbedaan yang nyata.

BerdasarkanTabel

dapatdilihat bahwa pekerja bengkel las memiliki kadar Cd lebih tinggi dibandingkan kelompok kontrol. Hal ini menunjukkan bahwa pekerja bengkel las mengalami keracunan Cd. Nogue et al, (2004) menyatakan bahwa pekerja las mengalami paparan $\mathrm{Cd}$ lebih tinggi dibandingkan pekerja bukan pengelasan seperti karyawan kantor.Pada proses pengelasan dihasilkan asap yang mengandung $\mathrm{Cd}^{2+}$ dan Cd oksida (CdO) yang dapat masuk tubuh pekerja bengkel las lewat jalur inhalasi. Sekitar 10 subyek kontrol dianalisis menggunakan uji t independent.

\section{HASIL DAN PEMBAHASAN}

\section{Kadar Cd darah}

Hasil kadar Cd darah dari subyek kontrol dan subyek kasus dapat dilihat pada Tabel 1. 
menimbulkan kecelakaan kerja. mengonsumsi sayur dan buah yang Menurut Suryanto, dkk (2016) kecelakaan kerja dapat terjadi oleh beberapa faktor seperti faktor dari individu pekerja (fisik) dan perilaku dan faktor lingkungan.

Pada subyek kontrol juga terkontaminasi Cd, yang ditanam di daerah perkebunan yang tercemar pestisida (Chunhabundit, 2016).

\section{Kadar Kreatinin darah}

Hasil kadar kreatinin darah ditemukan Cd dalam darah dari subyek kontrol dan subyek kasus kemungkinan disebabkan karena dapat dilihat pada Tabel 2.

Tabel 2.Kadar kreatinin pada subyekkontrol dan subyek kasus.

\begin{tabular}{ll}
\hline Kelompok & Kadar kreatinin darah (mg/dL) \\
Subyek kontrol & $0,76 \pm 0,02^{\mathrm{a}}$ \\
Subyek kasus & $1,58 \pm 0,07^{\mathrm{b}}$
\end{tabular}

Keterangan: $\mathrm{p}=0, \mathrm{n}=30$. Angka yang diikuti huruf yangtidak sama pada setiap kolom menunjukkan perbedaan yang nyata.

Hasil penelitian menunjukkan pada subyek kasus memiliki kadar kreatinin darah lebih tinggi dibanding dengan subyek kontrol dan nilai kreatinin pada subyek kasus telah melebihi nilai normal kreatinin darah yaitu $>0,7-1,3 \quad \mathrm{mg} / \mathrm{dL}$ (Akessonet al., 2014).

Peningkatan kadar kreatinin disebabkan karena kadmium yang masuk tubuh akan berikatan dengan protein metalotionin. Kadmium akan terakumulasi di hati sebesar 30\% dan di ginjal sebesar 30\%. Ikatan Cd dengan metalotionin dalam hati dan ginjal akan meningkatkan produksi radikal bebas dalam tubuh seperti anion superoksida, radikal hidroksil dan hidrogen peroksida. Hal ini akan menimbulkan reaksi berantai peroksidasi lipid yang dapat menimbulkan gangguan fungsi ginjal berupa penurunan laju filtrasi glomerulus (LFG). Penurunan LFG ditandai dengan peningkatan kadar kreatinin darah (Kim et al., 2015).

Kreatinin merupakan hasil metabolism dari kreatin dan fosfokreatin. Kreatinin memiliki berat molekul 113-Da (Dalton). Kreatinin difiltrasi di glomerulus dan direabsorpsi di tubulus ginjal. Jika 
terjadi disfungsi pada ginjal dan penurunan LFG maka kemampuan filtrasi ginjal terhadap kreatinin akan berkurang,sehingg kreatinin serum akan meningkat. Peningkatan kadar kreatinin serum dua kali lipat mengindikasikan adanya penurunanfungsi ginjal sebesar $50 \%$ (Alfonso et al., 2016).

Penelitian pada petani buah di daerah Maesot di Thailand juga ditemukan bahwa petani di daerah tersebut terpapar $\mathrm{Cd}$ dan mengalami penurunan fungsi ginjal.
Penurunan fungs ginjal ditandai dengan peningkatan kadar $\beta 2$ microglobulin, proteinuria, peningkatan ekskresi fosfat, hipokalemia dan laju filtrasi glomerulus (GFR) yang rendah (Swaddiwudhipong,et al., 2007;Limpatanachoteet al., 2009).

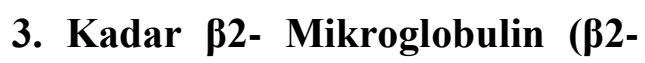
M)

Hasil pengukuran kadar $\beta 2-\mathrm{M}$ darah subyek kontrol dan subyek kasus dapat dilihat pada Tabel 3.

Tabel 3. Kadarß2-M pada subyek kontrol dan subyek kasus

\begin{tabular}{ll}
\hline Kelompok & Kadar $\beta 2-\mathrm{M}()$ \\
Subyek kontrol & $9,5 \pm 1,43^{\mathrm{a}}$ \\
Subyek kasus & $20,54 \pm 10,71^{\mathrm{b}}$ \\
\hline
\end{tabular}

Keterangan: $\mathrm{p}=0, \mathrm{n}=30$. Angka yang diikuti huruf yangtidak sama pada setiap kolom menunjukkan perbedaan yang nyata.

Peningkatan kadar $\beta 2-\mathrm{M}$ pada subyek kasus disebabkan karena mereka sehari-hari mengalami paparan Cd lewat jalur inhalasi. $\beta 2$ mikroglobulin merupakan polipeptida dengan berat molekul $11.8 \mathrm{kDa}$, banyak dijumpai pada permukaan sel berinti pada manusia dan merupakan bagian dari sistem Human Leucocyte Antigen (HLA) dan merupakan parameter untuk deteksi dini pada gangguan fungsi ginjal. Kadar $\beta 2-\mathrm{M}$ akan semakin meningkat apabila terjadi penurunan laju filtrasi glomerulus (Liabeuf et al., 2012)

$$
\text { Paparan Cd akan }
$$
menyebabkan kerusakan membran tubulus proksimal ginjal termasuk penurunan fluiditas, kerusakan protein membran dan perubahan homeostatis kalsium, karena kalsium 


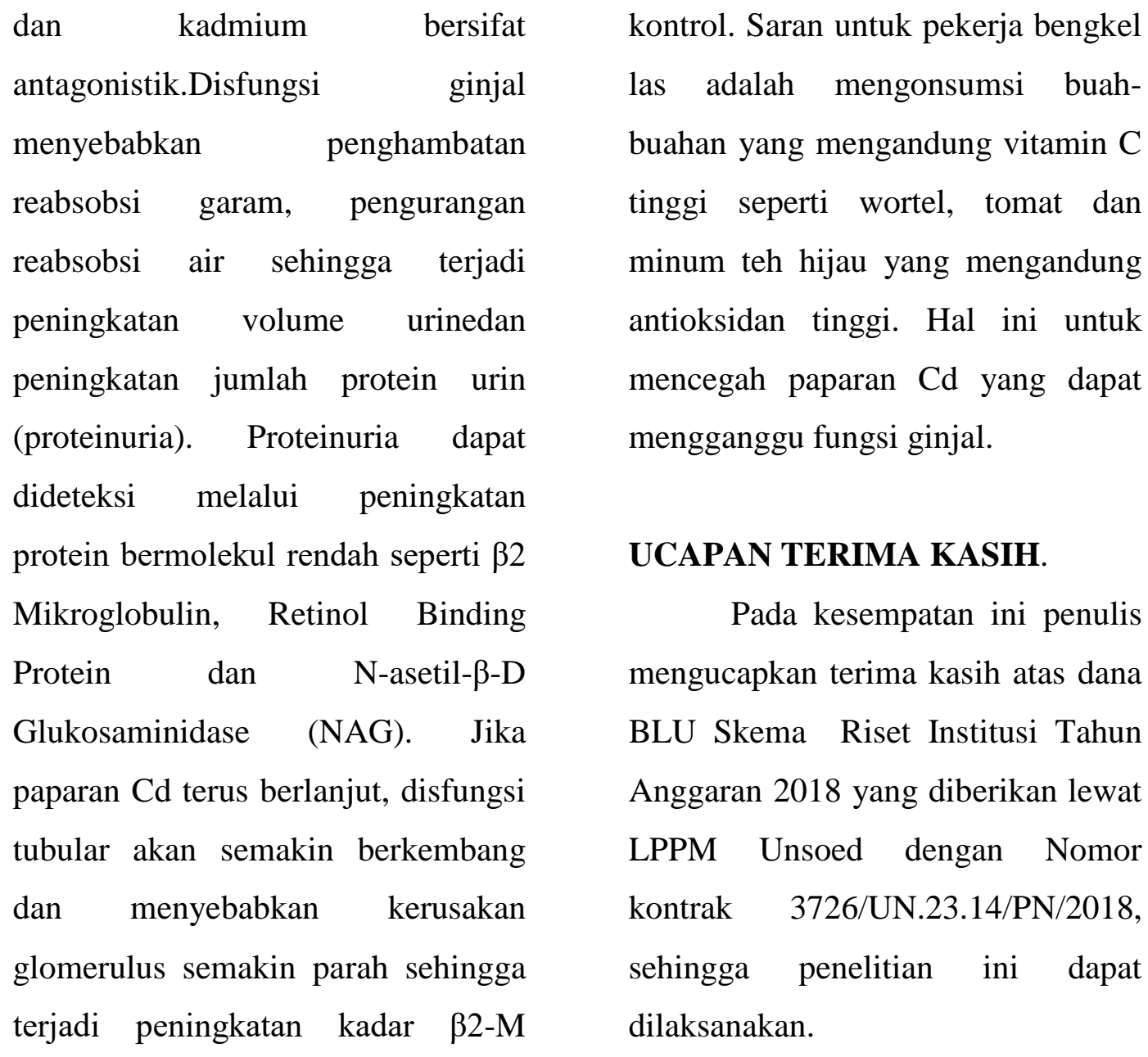

disertai dengan penurunan Laju

Filtrasi Glomerulus (Johri et al, 2010., Camila, 2013., Bernhoft. 2013).

\section{SIMPULAN DAN SARAN}

Paparan Cd menyebabkan penurunan fungsi ginjal pada pekerja bengkel las yang ditandai dengan peningkatan kadar Cd darah, kreatinin dan kadar $\beta 2-\mathrm{M}$ darah.Kadar ketiga parameter tersebut pada subyek kasus lebih tinggi dibandingkan dengan subyek

\section{DAFTAR PUSTAKA}

Alfonso, A.A, A.E. Morgan and M.F. Memah.2016. Gambaran kadar kreatinin serum pada pasien penyakit ginjal kronik stadium 5 non dialysis. Jurnal e-Biomedik (eBm) 4:1.

Bernard, A. 2008. Cadmium \& its adverse effects on human health. Indian $J$ MedRes 128 (10) : 557-564.

Chunhabundit, R. 2016. Cadmium Exposure and Potential Health Risk from Foods in Contaminated Area, Thailand.Toxicol. Res. 32(1): 65-72.

Faroon, O., Ashizawa, A., Wright, S., Tucker, P., Jenkins, K.,Ingerman, L. and Rudisill, C. 2012. Toxicological profile of cadmium, 
agency for toxic substances and disease registry.Atlanta, 273-274.

Johri, N., J. Gregory and U. Robert.2010. Heavy metal poisoning the effects of cadmium on the kidney. Biometals : 23 : 783-792.

Kim, N.H., Hyun, Y.Y., Lee, K.B., Chang, Y., Rhu, S., Oh, K.H. and Ahn, C, 2015 Environmental heavy metal exposure and chronic kidney disease in the general population. J.Korean Med. Sci., 30: 272-277.

Liabeuf S, Lenglet A, Desjardins L, Neirynck N, Glorieux G, Lemke HD. 2012. Plasma beta-2 microglobulin is associated with cardiovascular disease in uremic patients. Kidney Int 82:1297-303.

Nogue, S., S.Pere., T. Albert and B. Fransisco.2004. Chronic over exposure to Cadmium fumes associated with IgA mesangial glomerulonephritis, Occupational Medicine. 54 : 265-267.

Palar,H, 2008. Pencemaran dan toksikologi logam berat. P.T. Rineka Cipta Jakarta.
Santoso, S dan Hernayanti.2016. Efek paparan kadmium terhadap tekanan darah pekerja bengkel las. Proseding Seminar Nasional Pengembangan Sumberdaya Pedesaan dan Kearifan Lokal Berkelanjutan VI.

Suryanto, Anam,A dan Andodo, C, 2016. Pencegahan Kecelakaan Kerja Berbasis Human and Technical Approach di Purwokerto Utara. Jurnal Kesmas Indonesia 8(2):8091.

Swaddiwudhipong, W., Limpatanachote, P., Mahasakpan, P.,Krintratun, S. and Padungtod, C. 2007. Cadmiumexposed population in Mae Sot District, Tak Province: 1. Prevalence of high urinary cadmium levels in the adults. $J$. Med. Assoc.Thailand, 90 : 143-148.

Wohingati, Laksana, A.S dan Hernayanti. 2014. Pengaruh paparan kadmium (Cd) terhadap estimasi Laju Filtrasi Glomerulus pada petani tanaman hias di Baturaden.Skripsi Fakultas Kedokteran Unsoed (tidak dipublikasikan). 